\title{
Determination of Metals Contamination in Illicit Ecstasy Drug Samples Using ICP-OES and XRF
}

\author{
Taner Bora ${ }^{a *}$, Hasan Aydin ${ }^{\mathrm{b}}$, Yasin Atac ${ }^{\mathrm{a}}$, Nilgun Sen ${ }^{\mathrm{c}}$, and Cagdas Aksoy ${ }^{\mathrm{d}}$ \\ a Antalya Criminal Police Laboratory, 07310, Muratpasa, Antalya, Turkey \\ ${ }^{b}$ Gazi University, Department of Chemistry, 06500, Besevler, Ankara, Turkey \\ c Headquarters of Criminal Police Laboratories, 06830, Golbasi, Ankara, Turkey \\ d Diyarbakır Criminal Police Laboratory, 21010, Sehitlik, Diyarbakir, Turkey
}

\begin{abstract}
The analysis of 248 illegal "ecstasy" tablets was performed by determining 11 elements $(\mathrm{Zn}$, $\mathrm{Al}, \mathrm{Ca}, \mathrm{Mg}, \mathrm{K}, \mathrm{Na}, \mathrm{Ba}, \mathrm{Fe}, \mathrm{B}, \mathrm{Cu}$, and $\mathrm{Pt}$ ). The sample solutions were prepared with nitric acid, heated in a microwave oven, and analyzed by inductively coupled plasma optical emission spectrometry (ICP-OES). However, the measurement of $\mathrm{Pt}$ residuals from $\mathrm{PtO}_{2}$ (which is frequently used as the catalyst during the synthesis stage of the
\end{abstract}

active substance) was performed by X-ray fluoresence (XRF) analysis.

The determination of boron residuals revealed that $\mathrm{NaBH}_{4}$ was used in the production process. Barium was found to be present below the $0.1 \mu \mathrm{g} / \mathrm{g}$ level, but zinc was at 1.4 to $22.2 \mu \mathrm{g} / \mathrm{g}$, aluminum at 10.8 to $350.3 \mu \mathrm{g} / \mathrm{g}$, calcium at 33.4 to $416.8 \mu \mathrm{g} / \mathrm{g}$ ), magnesium at 89.0 to $2474.4 \mu \mathrm{g} / \mathrm{g}$, potassium at 12.4 to $88.7 \mu \mathrm{g} / \mathrm{g}$, sodium at 90.6 to $4543.2 \mu \mathrm{g} / \mathrm{g}$, iron at 1.6 to $654.6 \mu \mathrm{g} / \mathrm{g}$, and copper at 0.1 to $3.7 \mu \mathrm{g} / \mathrm{g}$. (b) Tablets containing at least one substance, i.e., caffeine, paracetamol, theophylline, meta-chlorophenylpiperazine (m-CPP), diphenylhydramine, etc., as an additive in addition to the amphetamine-type stimulants (ATS).

(c) Tablets containing at least one of the additives, i.e., m-CPP, caffeine, paracetamol, or theophylline, but not any of the ATSs.

(d) Tablets not containing any of the ATSs and other additives (fake tablets).

(e) Tablets containing other organic (stimulants, medicine-active agents, heroin, pesticides) and/or inorganic chemicals apart from the active agents evaluated as ATSs and additives.
MDMA (3,4-methylenedioxy-Nmethamphetamine) is an empathogenic drug of the amphetamine and amphetamine-type stimulants (ATS) and has become known and sold as "ecstasy" in tablet form in Turkey since the year 2000 (1). Even though there was a decrease in use after 2007 , the rate of ecstasy tablets sold was still high. The number of ecstasy and captagon (including amphetamine) tablets seized between 2007 and 2011 is presented in Figure 1 (2).

The chemical content of these seized illegal tablets can be classified in general as follows:

(a) Tablets containing at least one of the amphetamine-type stimulants, i.e., MDMA, amphetamine, methamphetamine, 3,4-methylenedioxyamphetamine (MDA), 3,4-methylenedioxyethylamphetamine (MDEA), etc.

*Corresponding autbor.

E-mail: taner.bora@egm.gov.tr

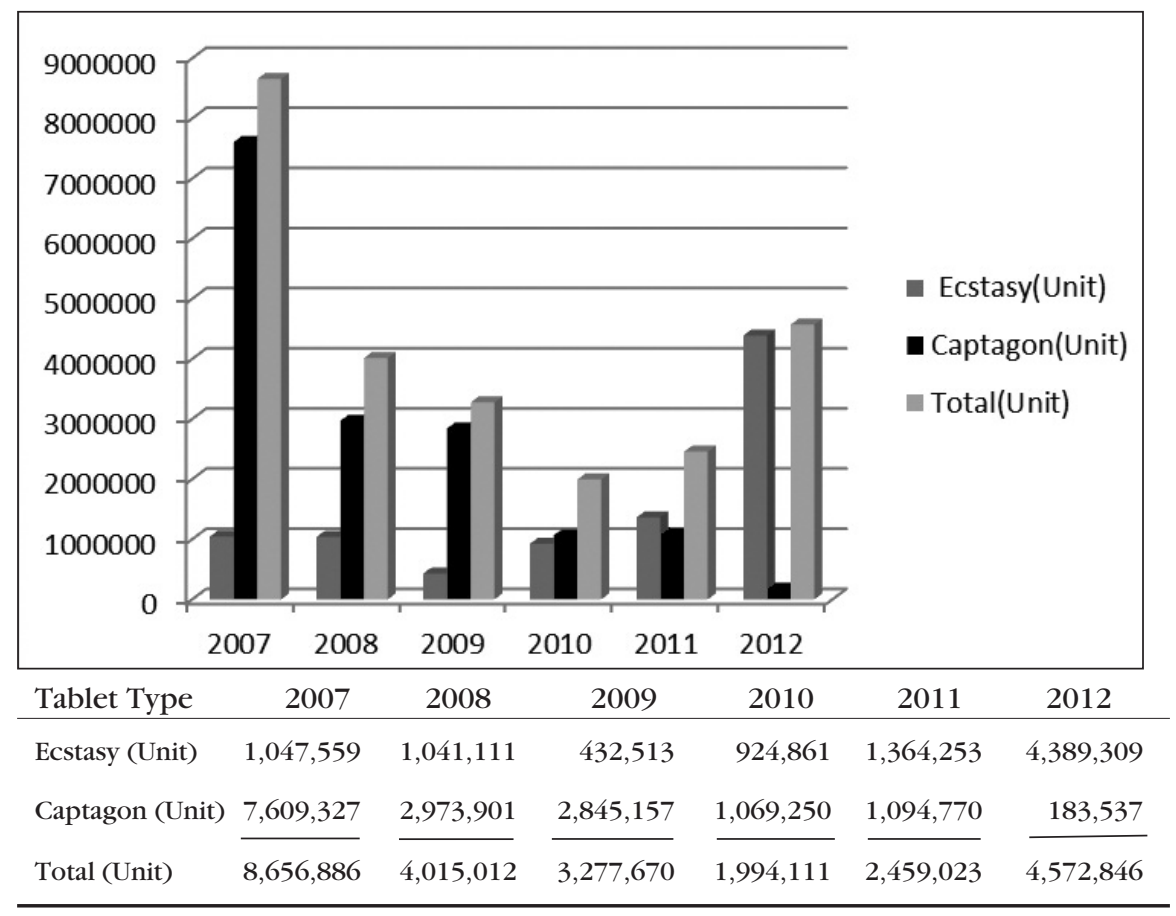

Fig. 1. The number of ecstasy and captagon tablets seized in Turkey between 2007 and 2012. 
The above-mentioned five tablet forms $(a-e)$ have different chemical content and are also different in terms of their metallic residuals content.

The stimulant tablets mostly encountered in Turkey are amphetamine and MDMA. Both forms are generally produced with caffeine and/or paracetamol and/or theophylline, in addition to the tablets that include amphetamine only. The substance of m-CPP (under restriction in Turkey since 2009) was primarily added as an additive to amphetamine and accepted as an active agent by itself; however, use of $\mathrm{m}-\mathrm{CPP}$ in illegal synthetic tablets has recently diminished. Tablets containing MDMA were primarily used in addition to tablets containing caffeine and/or paracetamol.

The majority of studies carried out for illicit drugs identify the organic structures as by-products and the intermediate products through synthesis, separation of active agents, and their qualitative and quantitative metals determination using an appropriate solvent, etc. (3-16). Studies performed to determine the metallic content of the tablets have been few in comparison to those identifying the organic structures. When analyzing the metallic content, the production methods used for the various drugs, the similarities and differences between the samples, the source determination and effects upon human health have been discussed (17-25). Bora et al. (19) determined 10 elements (Al, $\mathrm{Ba}, \mathrm{Ca}, \mathrm{Cu}, \mathrm{Fe}, \mathrm{Mg}, \mathrm{Mn}, \mathrm{Cd}, \mathrm{Pb}$, and $\mathrm{Zn}$ ) in seized heroin samples using atomic absorption spectrometry (AAS) and inductively coupled plasma atomic emission spectrometry (ICP-AES). Infante et al. (23) determined $\mathrm{Cd} \mathrm{Ca}, \mathrm{Cu}, \mathrm{Fe}, \mathrm{Mn}$, and $\mathrm{Zn}$ in 198 heroin samples using AAS. Chan et al. (24-25) performed quantitative analysis of 16 elements ( $\mathrm{Na}, \mathrm{Mg}, \mathrm{Al}, \mathrm{K}, \mathrm{Ca}, \mathrm{Cr}, \mathrm{Mn}, \mathrm{Fe}, \mathrm{Ni}$,
$\mathrm{Cu}, \mathrm{Zn}$, As, Se, Cd, Ba, and $\mathrm{Pb}$ ) in 309 heroin samples using inductively coupled plasma mass spectrometry (ICP-MS). Zhang et al. (22) revealed that neutron activation analysis (NAA) was possible for source determination of drugs and performed the analysis of 15 elements ( $\mathrm{Au}, \mathrm{Ba}, \mathrm{Br}, \mathrm{Ca}, \mathrm{Ce}, \mathrm{Co}, \mathrm{Cr}$, $\mathrm{Fe}, \mathrm{La}, \mathrm{Na}, \mathrm{Sb}, \mathrm{Sc}, \mathrm{Sm}$, Th, and $\mathrm{Zn}$ ) in 62 heroin samples. Waddel et al. (18) determined 12 metals ( $\mathrm{Li}, \mathrm{B}, \mathrm{V}$, Cr, Mn, Ni, Cu, Zn, Br, Sr, Sn, Ba, $\mathrm{Pt}$, and $\mathrm{Pb}$ ) in ecstasy tablets. Koper et al. (20) determined $\mathrm{Al}, \mathrm{B}, \mathrm{Ca}, \mathrm{Cr}$, $\mathrm{Fe}, \mathrm{Mg}, \mathrm{Mn}, \mathrm{Na}, \mathrm{P}, \mathrm{Pt}, \mathrm{S}, \mathrm{Cu}, \mathrm{Hg}, \mathrm{Li}$, $\mathrm{Nd}, \mathrm{Ni}, \mathrm{Rb}, \mathrm{Sn}$, Th, U, Y, and $\mathrm{Zn}$ in ecstasy tablets using ICP-AES and inductively coupled plasma mass spectrometry (ICP-MS), and in particular, the presence of $\mathrm{Pt}$ and $\mathrm{B}$ was emphasized.

In the present study, 11 elements were determined which accumulate during the various stages of the manufacturing process of the ecstasy tablets from the catalysts, reducers, fillers, cutting agents, paints, and other chemicals $(1,3,19)$ leaching out from the tablet manufacturing equipment. The quantitative ICP-OES determination of 10 elements ( $\mathrm{Zn}, \mathrm{Al}, \mathrm{Ca}, \mathrm{Mg}, \mathrm{K}, \mathrm{Na}, \mathrm{Ba}$, $\mathrm{Fe}, \mathrm{B}$, and $\mathrm{Cu}$ ) was performed by first dissolving the samples in a microwave oven $(1,19)$ with concentrated $\mathrm{HNO}_{3}$. The qualitative determination of Pt at trace levels was performed by XRF analysis.

\section{EXPERIMENTAL}

\section{ICP-OES Instrumentation}

The ICP-OES analyses were carried out using a PerkinElmer ${ }^{\circledR}$ Optima $^{\mathrm{TM}} 5300$ DV spectrometer. The instrumental operating conditions and analytical wavelengths are listed in Table I. The following elements were determined: $\mathrm{Zn}, \mathrm{Al}, \mathrm{Ca}$, $\mathrm{Mg}, \mathrm{K}, \mathrm{Na}, \mathrm{Ba}, \mathrm{Fe}, \mathrm{B}$, and $\mathrm{Cu}$. The values of the 10 elements measured by ICP-OES $\left(\mathrm{mg} \mathrm{L}^{-1}\right)$ are listed in Table II.

\section{X-Ray Fluorescence (XRF)}

The Pt determinations in the tablets were performed with a Spectro X-LAB 2000 X-ray fluorescence spectrometer, equipped with three different energy-directed polarization techniques using Mo, $\mathrm{Al}_{2} \mathrm{O}_{3}$ and High Oriented Pyrolitic Graphite (HOPG) (Spectro Analytical Instruments $\mathrm{GmbH}$, Germany). In this study, the HOPG analysis technique was used which is recognized as being appropriate for the Pt group elements. The XRF spectrum of a C4-coded tablet is demonstrated in Figure 2, highlighting the platinum peak. The concentrations of platinum in the ecstasy tablets analyzed by XRF are also listed in Table II.
TABLE I

ICP-OES Operating Conditions and the Analytic Wavelengths of the Elements

\begin{tabular}{|c|c|}
\hline RF Power & $1.3 \mathrm{~kW}$ \\
\hline Radio Frequency & $40 \mathrm{MHz}$ \\
\hline $\begin{array}{l}\text { Minimum Carrier } \\
\text { Gas Flow Rate }\end{array}$ & $0.8 \mathrm{~mL} \mathrm{~min}^{-1}$ \\
\hline Auxiliary Gas Rate & $0.2 \mathrm{~mL} \mathrm{~min}^{-1}$ \\
\hline Plasma Gas Flow Rate & $15 \mathrm{~L} \mathrm{~min}^{-1}$ \\
\hline Pump Uptake & $1.2 \mathrm{~mL} \mathrm{~min}^{-1}$ \\
\hline $\begin{array}{l}\text { Analytical Wavelengths } \\
(\mathrm{nm})\end{array}$ & $\begin{array}{l}\text { Zn 206.200, Ba 233.527, Al 396,153, Fe 238.204, } \\
\text { Ca } 317.933, \mathrm{Cu} 327.393, \mathrm{Mg} 285.213, \mathrm{~K} 766.490, \\
\mathrm{Na} 589.592, \mathrm{~B} 249.677\end{array}$ \\
\hline
\end{tabular}




\section{Atomic \\ Vol. 35(4), July/August 2014}

TABLE II

Values of 10 Elements Analyzed in Ecstasy Tablets by ICP-OES ( $\left.\mathrm{mg} \mathrm{L}^{-1}\right)$ and Pt by XRF

\begin{tabular}{|c|c|c|c|c|c|c|c|c|c|c|c|}
\hline Group & $\mathrm{Zn}$ & $\mathrm{Al}$ & $\mathrm{Ca}$ & $\mathrm{Mg}$ & $\mathrm{K}$ & $\mathrm{Na}$ & $\mathrm{Ba}$ & $\mathrm{Fe}$ & $\mathrm{B}$ & $\mathrm{Cu}$ & $\mathrm{Pt}$ \\
\hline A1 & 7.1 & 350.3 & 194 & 181 & 22.4 & 301 & $*$ & 13.7 & 65.4 & 2.1 & - \\
\hline A2 & 5.1 & 14.0 & 194 & 175 & 22.9 & 285 & $*$ & 21.0 & 80.0 & 2.1 & - \\
\hline A3 & 12.4 & 15.2 & 308 & 171 & 25.9 & 256 & $*$ & 20.9 & 206.3 & 0.2 & - \\
\hline A4 & 22.2 & 13.5 & 161 & 171 & 19.4 & 297 & $*$ & 176.1 & 119.6 & 0.4 & - \\
\hline A5 & 2.3 & 14.1 & 190 & 170 & 21.2 & 388 & $*$ & 21.0 & 200.0 & 0.8 & - \\
\hline A 6 & 4.6 & 15.0 & 200 & 175 & 20.9 & 291 & $*$ & 25.5 & 176.6 & 0.5 & - \\
\hline B1 & 1.9 & 22.0 & 80 & 926 & 80.0 & 129 & * & 36.8 & 1.1 & 0.6 & + \\
\hline $\mathrm{B} 2$ & 1.8 & 21.0 & 73 & 900 & 75.2 & 116 & $*$ & 36.6 & * & 0.5 & + \\
\hline B3 & 2.0 & 21.9 & 74 & 846 & 88.7 & 119 & $*$ & 30.0 & $*$ & 0.6 & + \\
\hline B4 & 1.7 & 29.5 & 75 & 969 & 74.9 & 90 & $*$ & 18.8 & $*$ & 0.5 & + \\
\hline B5 & 2.5 & 19.1 & 78 & 914 & 75.5 & 113 & $*$ & 34.8 & $*$ & 0.4 & + \\
\hline B6 & 2.9 & 32.0 & 101 & 550 & 75.0 & 110 & $*$ & 11.4 & * & 0.4 & + \\
\hline B7 & 6.1 & 28.5 & 416 & 432 & 73.2 & 131 & $*$ & 20.1 & 3.0 & 0.6 & + \\
\hline B8 & 1.7 & 22.0 & 64 & 845 & 85.9 & 114 & $*$ & 25.6 & * & 0.5 & + \\
\hline B9 & 1.4 & 24.6 & 70 & 920 & 21.5 & 109 & $*$ & 22.8 & $*$ & 0.6 & + \\
\hline B10 & 1.7 & 31.2 & 67 & 523 & 70.5 & 122 & $*$ & 23.1 & $*$ & 0.7 & + \\
\hline B11 & 1.4 & 44.3 & 112 & 1200 & 56.4 & 227 & $*$ & 88.9 & $*$ & 2.1 & + \\
\hline B12 & 3.1 & 25.6 & 70 & 840 & 78.3 & 121 & $*$ & 24.4 & $*$ & 0.4 & + \\
\hline B13 & 1.9 & 42.0 & 59 & 930 & 82.0 & 114 & $*$ & 21.1 & $*$ & 0.5 & + \\
\hline B14 & 3.2 & 21.2 & 70 & 865 & 83.8 & 110 & $*$ & 23.4 & $*$ & 0.6 & + \\
\hline C1 & 2.1 & 25.0 & 192 & 1450 & 18.4 & 2500 & $*$ & 15.4 & * & 1.8 & + \\
\hline $\mathrm{C} 2$ & 2.5 & 23.1 & 207 & 1265 & 23.8 & 4543 & $*$ & 6.9 & $*$ & 0.3 & + \\
\hline C3 & 2.4 & 23.6 & 186 & 1200 & 18.4 & 2562 & $*$ & 5.2 & $*$ & 2.1 & + \\
\hline C4 & 2.8 & 22.5 & 166 & 1113 & 17.9 & 2650 & $*$ & 26.8 & $*$ & 1.1 & + \\
\hline D1 & 2.5 & 14.3 & 182 & 633 & 20.0 & 560 & $*$ & 20.9 & $*$ & 0.3 & _ \\
\hline D2 & 1.8 & 15.5 & 251 & 644 & 24.4 & 720 & $*$ & 30.0 & $*$ & 1.2 & - \\
\hline D3 & 9.7 & 14.2 & 206 & 898 & 19.4 & 509 & $*$ & 15.5 & $*$ & 0.1 & 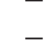 \\
\hline D4 & 2.3 & 22.4 & 312 & 150 & 34.3 & 323 & $*$ & 67.4 & $*$ & 0.9 & + \\
\hline E1 & 20.1 & 20.4 & 244 & 488 & 39.5 & 300 & $*$ & 82.4 & $*$ & 3.1 & - \\
\hline E2 & 15.7 & 23.8 & 207 & 2474 & 43.0 & 288 & $*$ & 25.9 & $*$ & 3.7 & - \\
\hline E3 & 17.8 & 20.5 & 233 & 1000 & 44.9 & 277 & $*$ & 28.1 & $*$ & 2.9 & - \\
\hline E4 & 16.0 & 21.9 & 228 & 720 & 40.2 & 295 & $*$ & 90.0 & $*$ & 2.9 & - \\
\hline F1 & 1.3 & 12.7 & 146 & 262 & 49.0 & 178 & $*$ & 4.4 & $*$ & 2.8 & - \\
\hline F2 & 1.3 & 11.9 & 155 & 230 & 46.0 & 182 & $*$ & 5.6 & $*$ & 2.6 & - \\
\hline F3 & 1.4 & 10.8 & 126 & 807 & 50.8 & 191 & $*$ & 5.4 & $*$ & 1.8 & - \\
\hline F4 & 1.4 & 10.8 & 116 & 755 & 47.8 & 188 & $*$ & 1.6 & $*$ & 0.1 & - \\
\hline G1 & 1.8 & 15.7 & 105 & 319 & 12.4 & 198 & $*$ & 12.5 & $*$ & 1.3 & + \\
\hline G2 & 2.3 & 120.6 & 142 & 881 & 42.7 & 507 & $*$ & 47.5 & $*$ & 1.2 & + \\
\hline G3 & 3.2 & 15.0 & 116 & 216 & 67.6 & 477 & $*$ & 76.8 & $*$ & 1.3 & + \\
\hline G4 & * & 24.8 & 290 & 89 & 22.1 & 252 & $*$ & 87.5 & $*$ & 3.8 & + \\
\hline H1 & $*$ & 30.3 & 300 & 860 & 54.7 & 224 & $*$ & 654.6 & * & 0.4 & + \\
\hline $\mathrm{H} 2$ & 0.1 & 27.4 & 243 & 3126 & 36.4 & 226 & $*$ & 119.8 & $*$ & 0.7 & + \\
\hline $\mathrm{H} 3$ & 0.2 & 14.1 & 135 & 2126 & 29.2 & 3509 & $*$ & 28.7 & $*$ & * & + \\
\hline H4 & 0.7 & 18.0 & 145 & 98 & 48.7 & 251 & $*$ & 7.42 & $*$ & $*$ & + \\
\hline K1 & 0.1 & 14.5 & 125 & 1997 & 29.6 & 593 & $*$ & 27.0 & $*$ & 2.2 & + \\
\hline $\mathrm{K} 2$ & 3.7 & 15.0 & 176 & 1839 & 37.4 & 507 & $*$ & 21.2 & $*$ & 0.5 & + \\
\hline K3 & 2.9 & 19.4 & 170 & 1200 & 32.2 & 472 & $*$ & 19.9 & $*$ & 0.6 & + \\
\hline K4 & 2.1 & 20.5 & 33 & 233 & 46.6 & 552 & $*$ & 45.7 & $*$ & 1.2 & + \\
\hline K5 & 3.5 & 19.3 & 196 & 976 & 42.7 & 501 & $*$ & 20.0 & $*$ & 1.0 & + \\
\hline
\end{tabular}

$*=<0.1 \mathrm{mg} \mathrm{L}^{-1}$ 


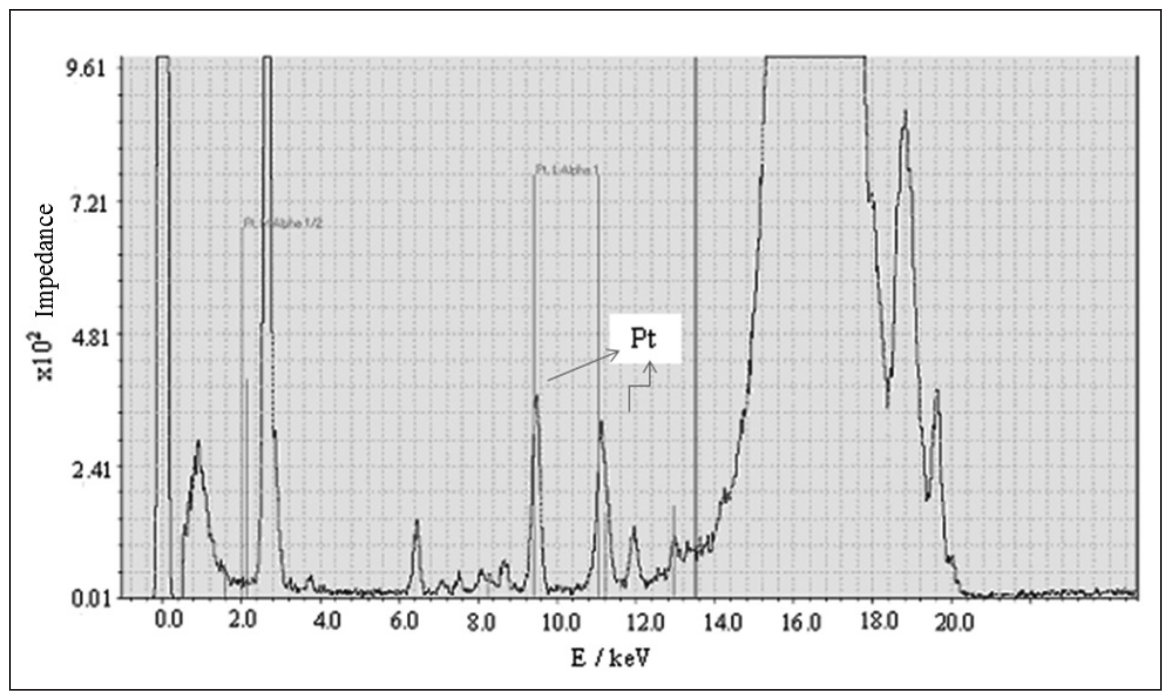

Fig. 2. XRF spectrum of C4 sample, indicating the Pt peak.

TABLE III

Temperature and Time Schedule in the Microwave Oven

\begin{tabular}{lrrrr}
\hline Step & \multicolumn{1}{c}{1} & 2 & \multicolumn{1}{c}{3} & \multicolumn{1}{c}{4} \\
\hline $\mathrm{T}{ }^{\circ} \mathrm{C}$ & 145 & 165 & 180 & 200 \\
Rate (min) & 5 & 2 & 2 & 2 \\
Wait (min) & 10 & 10 & 10 & 10 \\
\hline
\end{tabular}

\section{Microwave Oven}

A Berghoff speed wave MWS-3+ microwave sample dissolution system was used for decomposing the tablets (Berghoff Instruments, Germany). The temperature and time program is listed in Table III.

\section{Sample Selection and Sample Preparation}

The tablets used in this study and their physical properties are listed in Table IV. They were randomly chosen from a total of 248 synthetic tablets seized by the Ankara Police during 49 different illicit drug raids.

For the ICP-OES analysis, the samples were placed in a mortar and pulverized $(1,19)$. The crushed samples were weighed out as $300 \mathrm{mg} \pm 0.1 \mathrm{mg}$ on an analytical balance, then put into Teflon ${ }^{\circledR}$ (PTFE) sample vessels, and $3 \mathrm{~mL}$ $65 \%$ concentrated $\mathrm{HNO}_{3}$ was added. In order to prevent the solid particles from sticking to the inner walls of the vessels, instant heating was not applied and the vessels were left open for 20 minutes, then closed, and the dissolution process was finished using the microwave oven temperature-time schedule listed in Table III. The sample solution was brought to $10-\mathrm{mL}$ volume with Millipore ${ }^{\circledR}$ water and prepared for analysis. All measurements were obtained by reading each sample three times.

For the Pt determinations, the samples were qualitatively analyzed by taking $300 \mathrm{mg}$ of the crushed powder, spreading it over a transparent polypropylene film, and measuring it by X-ray fluorescence (XRF).

\section{Reagents and Reference Material}

Calibration curves for quantification were plotted by measuring the blanks and standard solutions within the concentration range of 0.1 and $20 \mu \mathrm{g} . \mathrm{mL}^{-1}$ depending on the element's response. Ultrapure (Type I) water obtained from a Direct-Q ${ }^{\circledR} 8$ UV system (Merck Millipore, France) was used for all dilutions. Nitric acid (\% 65, Merck, Germany) was of analytical purity. A reagent blank solution was prepared in accordance with the same procedure applied to the samples.

\section{RESULTS AND DISCUSSION}

Although the metal content of the ecstasy tablets analyzed may not cause sudden severe health problems, a frequent and overdose use of such illicit tablets by drug addicts can cause serious health problems. Additional negative effects to the addicts might also be due to the metallic content in ecstasy tablets.

The physical characteristics of the tablets having the same logo and coded with the same letters (A-K) were evaluated between each other within the same group and are listed in Table IV. The purpose of analyzing the tablets for their elemental content was to understand the metallic additions in all stages of production from tablet pressing to the containers used in the process of adding active agents, from filling materials and additives, catalysts, chemical intermediates and raw materials used during the tabletting stage. The minimum, maximum, and average values of the elements determined in the tablets by ICP-OES are listed according to their groups in Table V.

Among the 49 different codenumbered analyzed tablets, magnesium was the most concentrated element present in 32 , sodium in 14 , calcium in 2, and aluminum in 1 . Analysis of the samples showed that barium was present below $0.1 \mathrm{mg} \mathrm{L}^{-1}$. 


\section{Atomic Apectroscopy \\ 1 Vol. 35(4), July/August 2014}

TABLE IV

Details of Physical Characteristics of the Samples Seized and Analyzed

\begin{tabular}{|c|c|c|c|c|c|c|c|c|}
\hline $\begin{array}{l}\text { Sample } \\
\text { No. }\end{array}$ & Code & $\begin{array}{l}\text { Unit of } \\
\text { Tablet }\end{array}$ & Logo & Shape & Color & $\begin{array}{l}\text { Mass } \\
\text { (average } \\
\mathrm{mg})\end{array}$ & $\begin{array}{c}\text { Diameter } \\
\text { (average } \\
\mathrm{mm} \text { ) }\end{array}$ & $\begin{array}{c}\text { Thickness } \\
\text { (average } \\
\text { mm) }\end{array}$ \\
\hline 1 & A1 & 6 & $\mathbf{X X X}$ & Round & Yellow & 255.6 & 8.03 & 4.43 \\
\hline 2 & A2 & 3 & $\mathbf{x x x}$ & Round & Yellow & 245.3 & 8.03 & 4.38 \\
\hline 3 & A3 & 5 & $\mathbf{x x x}$ & Round & White & 243.7 & 8.04 & 4.50 \\
\hline 4 & A4 & 3 & $\mathbf{x x x}$ & Round & White & 242.5 & 8.05 & 4.05 \\
\hline 5 & A5 & 5 & $\mathrm{xxx}$ & Round & Rose & 200.1 & 8.09 & 3.35 \\
\hline 6 & A6 & 4 & $\mathbf{X X X}$ & Round & White & 257.6 & 8.02 & 4.55 \\
\hline 7 & B1 & 7 & Mitsubishi & Round & White & 217.2 & 7.11 & 4.60 \\
\hline 8 & $\mathrm{~B} 2$ & 5 & Mitsubishi & Round & White & 211.3 & 7.10 & 4.51 \\
\hline 9 & B3 & 6 & Mitsubishi & Round & White & 223.8 & 7.09 & 4.77 \\
\hline 10 & B4 & 3 & Mitsubishi & Round & White & 216.1 & 7.10 & 4.70 \\
\hline 11 & B5 & 4 & Mitsubishi & Round & White & 219.7 & 7.10 & 4.66 \\
\hline 12 & B6 & 4 & Mitsubishi & Round & White & 219.9 & 7.08 & 4.80 \\
\hline 13 & B7 & 5 & Mitsubishi & Round & White & 221.4 & 7.10 & 4.71 \\
\hline 14 & B8 & 6 & Mitsubishi & Round & White & 219.4 & 7.10 & 4.64 \\
\hline 15 & B9 & 4 & Mitsubishi & Round & White & 212.8 & 7.10 & 4.55 \\
\hline 16 & B10 & 5 & Mitsubishi & Round & White & 216.9 & 7.13 & 4.54 \\
\hline 17 & B11 & 4 & Mitsubishi & Round & White & 165.4 & 7.03 & 3.65 \\
\hline 18 & B12 & 8 & Mitsubishi & Round & White & 227.3 & 7.08 & 4.80 \\
\hline 19 & B13 & 5 & Mitsubishi & Round & White & 215.8 & 7.10 & 4.60 \\
\hline 20 & B14 & 5 & Mitsubishi & Round & White & 220.7 & 7.11 & 4.65 \\
\hline 21 & $\mathrm{C} 1$ & 4 & - & Heart & Rose & 298.8 & - & 5.90 \\
\hline 22 & $\mathrm{C} 2$ & 5 & - & Heart & Green & 233.5 & - & 4.78 \\
\hline 23 & $\mathrm{C} 3$ & 6 & - & Heart & Green & 236.5 & - & 5.00 \\
\hline 24 & $\mathrm{C} 4$ & 4 & - & Heart & Yellow & 265.5 & - & 5.37 \\
\hline 25 & D1 & 5 & Smiling Face & Round & Grey & 249.4 & 8.10 & 3.86 \\
\hline 26 & D2 & 4 & Smiling Face & Round & Brown & 241.0 & 8.10 & 3.80 \\
\hline 27 & D3 & 3 & Smiling Face & Round & Grey & 238.4 & 8.09 & 3.70 \\
\hline 28 & D4 & 3 & Smiling Face & Round & Yellow & 234.0 & 8.16 & 4.19 \\
\hline 29 & E1 & 10 & Captagon & Round & Yellow & 173.6 & 8.03 & 3.61 \\
\hline 30 & $\mathrm{E} 2$ & 8 & Captagon & Round & Rose & 174.3 & 8.00 & 3.63 \\
\hline 31 & E3 & 8 & Captagon & Round & Rose & 173.2 & 8.00 & 3.45 \\
\hline 32 & $\mathrm{E} 4$ & 9 & Captagon & Round & Yellow & 169.9 & 8.15 & 3.20 \\
\hline 33 & $\mathrm{~F} 1$ & 5 & Moon & Round & Beige & 285.8 & 9.15 & 3.60 \\
\hline 34 & $\mathrm{~F} 2$ & 4 & Moon & Round & Beige & 287.0 & 9.14 & 3.60 \\
\hline 35 & F3 & 4 & Moon & Round & Beige & 295.8 & 9.15 & 3.70 \\
\hline 36 & F4 & 6 & Moon & Round & Beige & 278.5 & 9.13 & 3.63 \\
\hline 37 & G1 & 5 & Diamond & Round & White & 241.3 & 8.02 & 4.30 \\
\hline 38 & G2 & 5 & Diamond & Round & White & 280.9 & 8.01 & 4.70 \\
\hline 39 & G3 & 5 & Diamond & Round & White & 275.5 & 8.00 & 4.65 \\
\hline 40 & G4 & 6 & Diamond & Round & Green & 238.4 & 9.00 & 3.15 \\
\hline 41 & H1 & 4 & 007 & Round & White & 284.5 & 8.04 & 4.60 \\
\hline 42 & $\mathrm{H} 2$ & 5 & 007 & Round & White & 296.9 & 8.07 & 4.66 \\
\hline 43 & $\mathrm{H} 3$ & 4 & 007 & Round & Blue & 203.4 & 8.07 & 3.50 \\
\hline 44 & $\mathrm{H} 4$ & 4 & 007 & Round & Yellow-White & e 237.7 & 8.17 & 4.40 \\
\hline 45 & K1 & 4 & Dollar & Round & Rose & 253.5 & 7.15 & 5.20 \\
\hline 46 & $\mathrm{~K} 2$ & 5 & Dollar & Round & Rose & 252.3 & 7.13 & 5.14 \\
\hline 47 & K3 & 6 & Dollar & Round & Rose & 254.6 & 7.15 & 5.30 \\
\hline 48 & K4 & 5 & Dollar & Round & Yellow & 242.4 & 7.15 & 5.36 \\
\hline 49 & K5 & 5 & Dollar & Round & Rose & 274.5 & 7.17 & 5.55 \\
\hline
\end{tabular}


TABLE V

Minimum, Maximum, and Average Values of the Elements Determined by ICP-OES (mg $\left.\mathrm{L}^{-1}\right)$

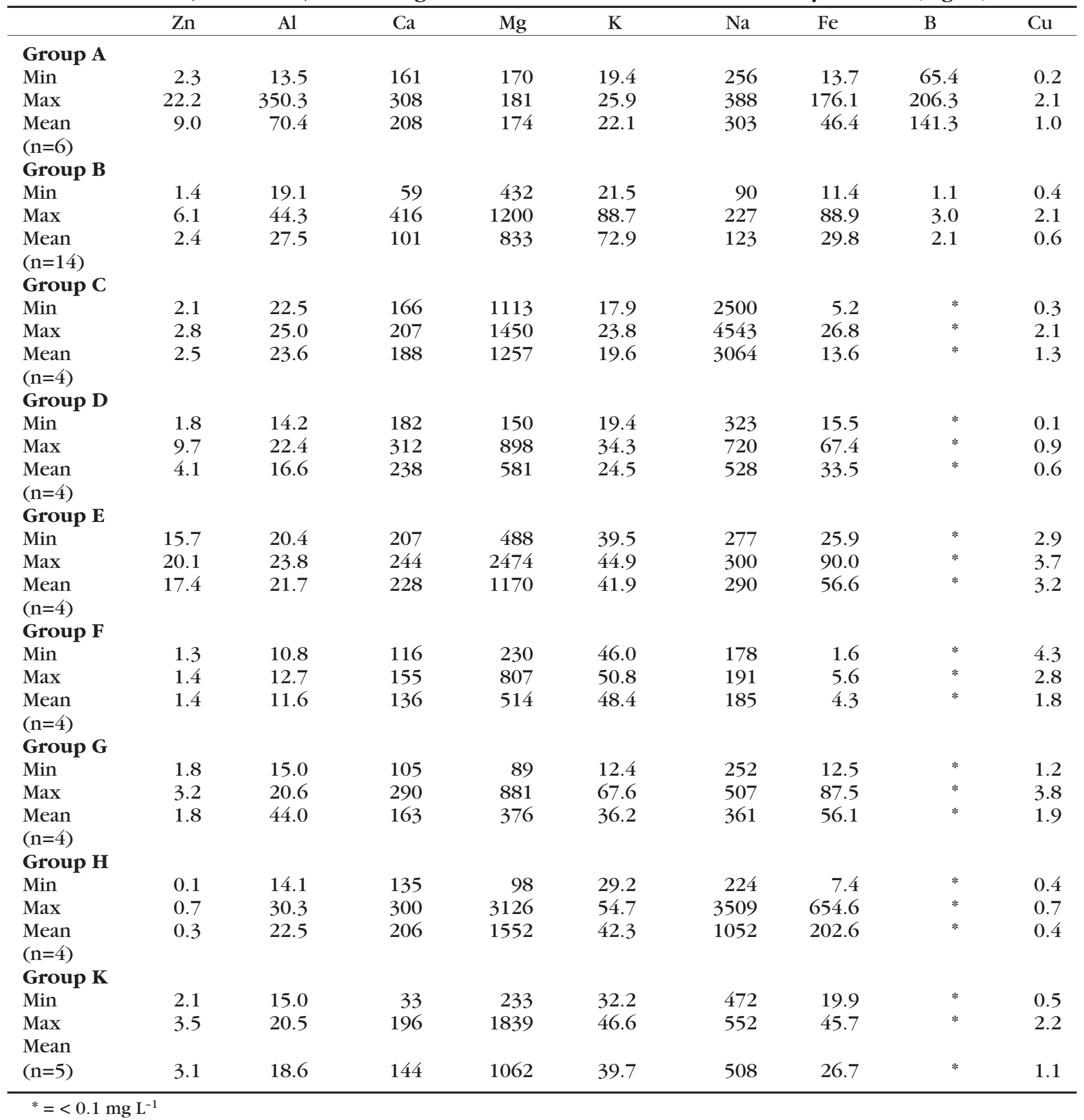


These data also revealed that no catalyst, including barium or a byproduct, was used to produce the tablets. In general, the sources for metallic impurities of the ecstasy tablets were found to come from the catalyst and the reducing agents used during the production process and include $\mathrm{Pt}, \mathrm{Fe}, \mathrm{B}, \mathrm{Mg}, \mathrm{Hg}$, $\mathrm{Li}$, $\mathrm{Pd}$, and $\mathrm{Ni}$ from additives and from filling materials such as $\mathrm{Al}, \mathrm{Mg}, \mathrm{Si}$, and $\mathrm{P}$, as well as from the coloring agents used for the tablets (20).

The most common method of producing MDMA through illegal techniques is the reduction of MDP-2-P $(3,4,5,7)$. In the MDMA production, the method is performed under pressure in which $\mathrm{PtO}_{2}$ is used as the catalyst for the reductive amination method (Figure $3 \mathrm{~b}$ ). In addition, the Cold Method, in which $\mathrm{NaBH}_{4}$ is the reducing agent, is one of the most frequently preferred methods (Figure $3 \mathrm{c}$ ). The most common method for amphetamine production is the LeuckartWallach method (Figure 3 a) for which formic acid is used as the reducing agent.

The boron and platinum values given in Table II probably attract the most attention. It was found that of the 49 samples, 30 samples contained Pt residuals, 2 samples contained both $\mathrm{Pt}$ and boron residuals, 6 samples contained boron residuals, and 11 samples contained neither boron nor Pt residuals. Although the samples containing boron were in the A-coded tablets, Pt was found in the B-, C-, G-, H(apart from $\mathrm{H} 4$ ), D4-. and $\mathrm{K}$-coded tablets. The tablets not containing boron and platinum were the D(apart from D4), E-, and F-coded tablets. Also different boron values were found in tablets containing boron.

In the A group tablets, the values of groups $\mathrm{Al}$ (aluminum): A3: Zn and $\mathrm{Ca} ; \mathrm{A} 4: \mathrm{Zn}$ and $\mathrm{Fe}$; and $\mathrm{A} 5: \mathrm{Na}$ were rather different than from the other A group tablets. Although differences in quantity were observed in all A group tablets, boron was detected at 65.4 $206.3 \mathrm{mg} / \mathrm{L}$. When boron was found as a residual, it was considered to come from the $\mathrm{NaBH}_{4}$ used in the Cold Method. In contrast, the presence of Pt (Figure 2) was considered to be from the $\mathrm{PtO}_{2}$ used as a catalyst. Moreover, the tablets not containing $\mathrm{Pt}$ and $\mathrm{B}$ proved that the amphetamine-type stimulant, synthesized with the Leuckart-Wallach method, also do not contain any active and cutting agents.

In the B-group tablets, the presence of Pt residuals proved that the active agents used in the production were completely different from the tablets included in the A group. The $\mathrm{B} 7$ tablets were found to have high calcium and low magnesium and the B11 tablets high magnesium, sodium, and iron. In the B1 and B7 tablets, both boron and platinum residuals were determined. However, the boron values of $\mathrm{B} 1$ and B7 were much lower than in the

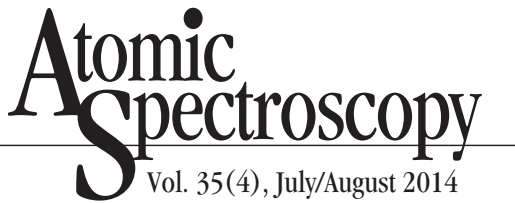

A-group tablets. This proves that boron in the $\mathrm{B} 1$ and $\mathrm{B} 7$ tablets can be contaminated by impurities from the previous production.

In the XRF analysis of the C-group tablets, Pt was determined as in the B-group tablets. Although the tablets in this group were not in general similar to each other, they had much higher concentrations for sodium, magnesium, and calcium than the other groups, which was a property common in the C-group.

Only the D4-coded tablets contained Pt residuals. When the tablets in this group were compared, the differences were quite remarkable. Furthermore, the $\mathrm{Al}, \mathrm{Ca}, \mathrm{Mg}$, $\mathrm{K}$, $\mathrm{Na}$, and $\mathrm{Fe}$ values within the impurities existing in the D4 tablets were significantly different from the concentrations found in the other tablets.

When the values related to the E-group were analyzed, it was noticed that the E1, E4, E2, and E3

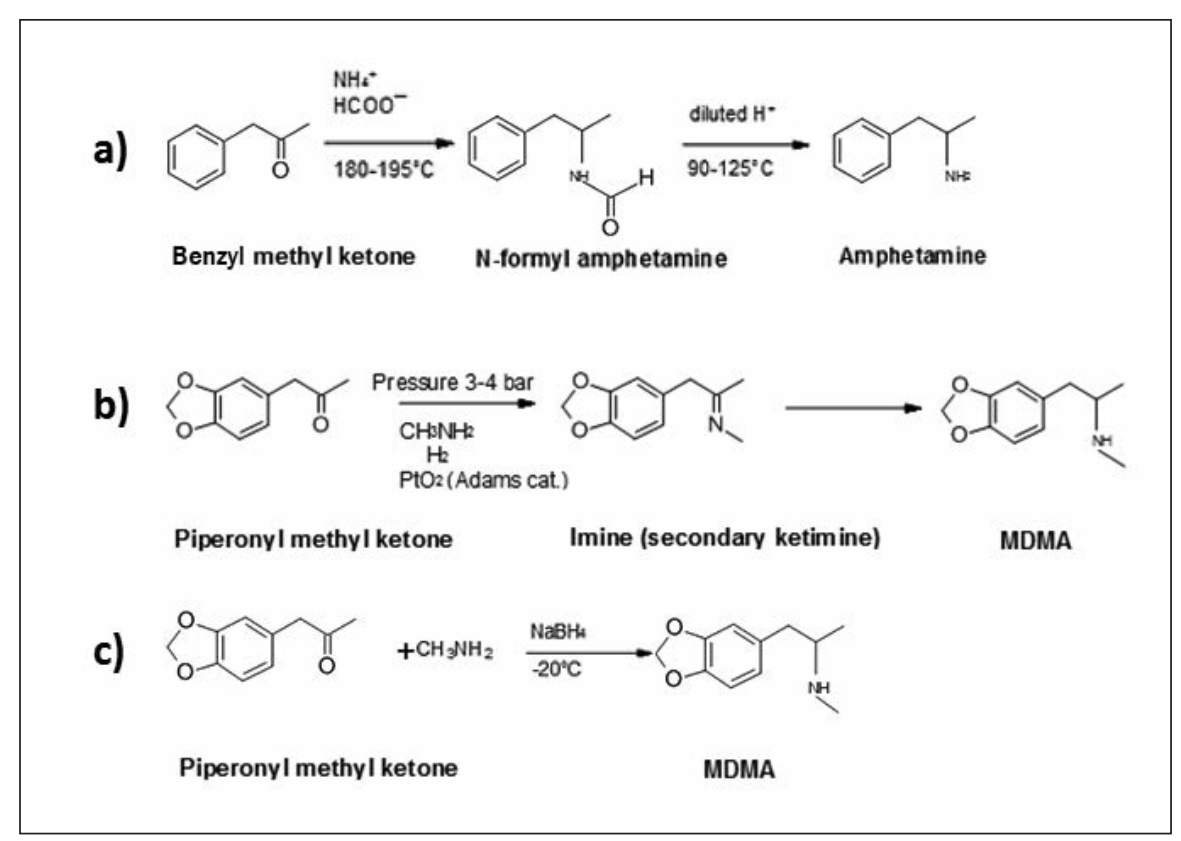

Fig. 3 (a, b. c). The most common methods used for production routes of illicit amphetamine and MDMA:

(a) Leuckart-Wallach Method for amphetamine production.

(b) Reductive Amination Under Pressure Method for MDMA production.

(c) Cold Method for MDMA production. 
tablets were similar to each other. The tablets not containing platinum and the captagon-logo tablets containing amphetamine suggested that the E-group tablets containing the amphetamine were produced with the Leuckart-Wallach method. The $\mathrm{Zn}$ amounts measured in this group were higher than the amounts found in the other groups.

In the F-group tablets, $\mathrm{B}$ and $\mathrm{Pt}$ were not present. When the values of the G-group tablets were analyzed, it was noticed that the metallic impurity levels of the F1 and F2 tablets were very similar within the scope of experimental error. In addition, the $\mathrm{F} 3$ and $\mathrm{F} 4$ metallic content values were similar to each other.

There were no significant differences between the values of the G-coded tablets. Pt was used as the catalyst in the production of the tablets in this group.

Another tablet group in which Pt was used as the catalyst was the H-group. There were no significant differences found between the H-group values.

In the K-group, the values of $\mathrm{K} 4$ were different in comparison to all other members of the group.

\section{CONCLUSION}

In this study, it was planned to establish a relationship between the different "ecstasy" tablets seized in the fight against illicit drugs. However, only the analysis of the elemental residuals was performed in order to understand the similarities and differences between the tablets in the various production processes. For instance, boron was present as a residual derived from sodium borohydride used as the reducing agent in the Cold Method process. Moreover, the Pt determined was found to be derived from $\mathrm{PtO}_{2}$ used as the Adams catalyst. The presence of $\mathrm{Mg}$ in the tablets was identified as coming from magnesium stearate which has lubricant properties and is necessary for shaping the tablets. Furthermore, the Ba levels revealed that barium compounds were not used in any of the stages of tablet production.

From this study, it can be concluded that the elemental determinations provided good agreement for the one-to-one comparison of the synthetic tablets. Moreover, the elemental values found verified that the chemical and physical properties of the tablets can be used as supporting evidence in identifying and establishing the differences between the various forms of illegal drugs.

Received May 26, 2014.

\section{REFERENCES}

1. T. Bora, Ph.D. Thesis, Gazi University, Ankara (2007).

2. Turkish Drug Report 2013, Ankara, 166,167 (2013).

3. P. Gimeno, F. Besacier, H. ChaudronThozet, J. Girard, and A. Lamotte, Forensic Sci. Int. 127, 1 (2002).

4. A.M.A. Verweij, Forensic Sci. Rev. 1(1), 1 (1989).

5. M. Świst, J. Wilamowski and A. Parczewski, Forensic Sci. Int. 152, 175 (2005).

6. M. Świst, J. Wilamowski, D. Zuba, J. Kochana and A. Parczewski, Forensic Sci. Int. 149, 181 (2005).

7. F. Palhol, S. Boyer, N. Naulet and M. Chabrillant, Anal. Bioanal. Chem. 374, 274 (2002)

8. H. Inoue, T. Kanamori, Y.T. Iwata, Y. Ohmae, K. Tsujikawa, S. Saitoh, and T. Kishi, Forensic Sci. Int. 135, 42 (2003).

9. F. Palhol, C. Lamoureux M. Chabrillat, and N. Naulet, Anal. Chim. Acta510 (1), 1 (2004).

10. C.S.L. Jonson, and N. Artizzu, Forensic Sci. Int. 93, 99 (1998).

11. P. Gimeno, F. Besacier, and H. Chaudron-Thozet, Forensic Sci. Int. 3543, 1 (2003).
12. J.Y.K. Cheng, M.F. Chan, T.W. Chan, and M.Y. Hung, Forensic Sci. Int. 162, 87 (2006).

13. R.J. Renton, J.S. Cowie, and M.C. Oon, Forensic Sci. Int. 60, 189 (1993).

14. D.R. Morello, S.D. Cooper, S. Panicker, and J.F. Casale, J. Forensic Sci. 55(1), 42 (2010).

15. V. Dufey, L. Dujourdy, F. Besacier, and $\mathrm{H}$. Chaudron, Forensic Sci. Int. 168, 108 (2007)

16. D. Zhang, X. Shi, Z. Yuan, and H. Ju, J. Forensic Sci. 49, 81 (2004).

17. M. Świst, J. Wilamowski, and A. Parczewski, Forensic Sci. Int. 155, 100 (2005).

18. R.J.H. Waddell, N. NicDaéid, and D. Littlejohn, Analyst 129, 235 (2004).

19. T. Bora, M. Merdivan, and C. Hamamc1, J. Forensic Sci. 47(5), 959 (2002).

20. C. Koper, C. van den Boom, W. Wiarda, M. Schrader, P. de Joode, G. van der Peijl, and A. Bolck, Forensic Sci. Int. 171(2-3), 171 (2007).

21. R. Myors, R.J. Well, S.V. Skopec, P. Crisp, R. Iaverz, Z. Skopec, A. Ekangaki, and J. Robertson, Anal. Commun. 35, 403 (1998)

22. Z.Y. Zhang, J.H. Yang, H. Ouyang, Z.J. Li, Z.F. Chai, J. Zhu, J.Z. Zhao, Z.S. Yu, and J. Wang, J. Radioanal. Nucl. Chem. 262, 295 (2004).

23. F. Infante, E. Domínguez, D. Trujillo, and A. Luna, J. Forensic Sci. 44, 110 (1999).

24. K.W. Chan, G.H. Tan, and R.C.S. Wong, Anal Lett. 45, 1122 (2012).

25. K.W. Chan, G.H. Tan, and R.C.S. Wong, Sci. Justice, 53, 73 (2013). 